\title{
Investigating the Effects of Welding Processes on Tensile Stress and Strain Properties of Welded Mild Steel Plates Using Statistical Analysis
}

\author{
Oladebeye Dayo Hephzibah ${ }^{1, *}$, Adejuyigbe Samuel Babatope ${ }^{2}$, \\ Olorunnishola Akim Abayomi Gideon ${ }^{1}$ \\ ${ }^{1}$ Department of Mechanical Engineering Technology, Federal Polytechnic, Ado-Ekiti, Nigeria \\ ${ }^{2}$ Mechatronics Engineering Department, Federal University, Oye-Ekiti, Nigeria
}

Email address:

dayobeye@yahoo.com (O. D. Hephzibah), solaakim73@gmail.com (O. D. Hephzibah)

${ }^{*}$ Corresponding author

\section{To cite this article:}

Oladebeye Dayo Hephzibah, Adejuyigbe Samuel Babatope, Olorunnishola Akim Abayomi Gideon. Investigating the Effects of Welding Processes on Tensile Stress and Strain Properties of Welded Mild Steel Plates Using Statistical Analysis. American Journal of Mechanical and Materials Engineering. Vol. 4, No. 3, 2020, pp. 43-47. doi: 10.11648/j.ajmme.20200403.11

Received: June 26, 2020; Accepted: July 13, 2020; Published: July 28, 2020

\begin{abstract}
As test samples, mild steel plates with thicknesses of $0.5 \mathrm{~mm}, 0.6 \mathrm{~mm}, 0.7 \mathrm{~mm}, 0.8 \mathrm{~mm}, 0.9 \mathrm{~mm}$, and $1.0 \mathrm{~mm}$ were made. After welding these test samples underwent Tensile Stress and strain tests with the Built Welding Robot and Manual Electric Arc Welding Machine. Both data collected from tensile stress and tensile stress were analyzed and the data produced from Electric Arc welding operations, the Robot welding operations and un-welded plates (control) were compared with one another. The analyses of the data obtained from the developed welding robot, manual electric arc welding and unwelded (control) mild steel plates of different thicknesses were carried out for tensile stress and strain. The descriptive statistics, ANOVA analysis, test of homogeneity of Variances and Post Hoc test (Least Significant Differences) were the statistical tools deployed using Statistical Package of Social Sciences (SPSS version 2016). The results showed that the robot welding sample produced gave the lowest tensile stress while the un-welded samples (CONTROL) gave the highest. The un-welded (CONTROL) samples gave the highest tensile strain values while the lowest was given by the developed robot welding samples. Finally, it was evident from the analyses results that the welding processes have significant impact on the tensile stress and strain properties of the welded mild steel plates and that good welding quality can be achieved more with the developed welding robot.
\end{abstract}

Keywords: Welding Processes, Tensile Stress, Tensile Strain, Mild Steel, Statistical Analysis

\section{Introduction}

At weld toes the crack initiation and early propagation is controlled by the distribution of local stress around the weld. Its fatigue analysis and evaluation already has a very long history [1]. Several researchers, including Peterson, Manson and Haibach, carried out initial investigations in the 1960's to link the frequency of fatigue to a local stress or strain measured at a certain point close to the weld toe, for example at a distance of $2 \mathrm{~mm}[2]$. While the characteristic strength of fatigue associated with this local stress shows a relatively low dispersion, it has been shown that it is indeed influenced by the local notch at the weld toe and is not independent of the local notch geometry [3]. Studies of relatively thick tubular joints found that the local notch effect of the weld toe has an effect on the stress in the region up to 0.3-0.4·t (t-plate thickness) away from the weld toe. This led to the development of the well-known hot-spot stress method in the 1970s, with the concept of reference points for stress assessment and extrapolation at certain distances away from the weld, which depend on the thickness of the plate or shell. This research investigation showed that the assessment of tubular joints fatigue strength due to their complex joint geometry and high local bending of the tubular walls was effective [4].

Early 1980 s also saw first attempts to apply the technique 
to welded joints on boards. Due to the local structural geometry of ship hull data, remarkable investigations were carried out in Japan to examine the stress concentration [5]. The construction stress was obtained by linearization of the stress via the thickness of the plate from finite-element analyses. Some investigations described structural stress at the hot spot (welded toe) as the surface stress that can be measured at the hot spot in accordance with the theories used in engineering structures [6]. He has shown that structural stress can be evaluated either by surface extrapolation or linearization, e.g. through the thickness of the wall, to exclude the local non-linear stress peak caused by the weld toe.

A generalized hot-spot stress approach was developed for plate structures in the early 1990's using Radaj's efficient noch stress approach and applied it to complex welded structures $[7,8]$. Specific guidelines on the determination of stress for fatigue analysis of welded components were provided. However, some experiments showed that the resulting stresses are still influenced by the meshing of finite elements and the properties of elements [9]. Additional recommendations were provided for finite element modeling and hot-spot stress assessment, the latter based on detailed round-robin stress analysis of several aspects. For in-plane notches such as welded edge gussets, where plate thickness is no longer a valid parameter for defining the reference points for stress evaluation, special considerations have been shown to be important $[10,11]$. In these cases, alternate methods were suggested for the hot-spot stress analysis, using absolute distances for the reference points [12, 13]. A systematic guidance for an approach to structural hot-spot stress is currently being prepared [14].

Radaj's structural stress description (1990) was used to measure the structural stress directly from the finite-element results at the weld toe position using elementary structural mechanics principles [15]. Several say and prove insensitivity to the mesh, however, mainly on $2 \mathrm{D}$ basic joints $[15,16]$. The various approaches for structural stress assessment were explained in more detail and contrasted with each other. Afterwards, numerous $2 \mathrm{D}$ and $3 \mathrm{D}$ examples demonstrated their implementation, demonstrating the similarity of the approaches and addressing the question, how far mesh-insensitivity can be achieved [17]. It has been emphasized that the structural stress approach was limited to the fatigue strength assessment of weld toes, where cracks start from the surface of the structure [18]. Cracks beginning from the root are not protected by completely penetrated welds and require a separate evaluation method [19].

Statistics is an integral component of engineering research from concept initiation to project reporting and it affects all facets of the research process, from data collection and management to review and interpretation. The application of statistics to the welding sciences, and especially in our area of interest, has become more widespread and complex to investigate the effects of welding processes on tensile stress and strain properties of welded mild steel plates.

Statistical methods involved in conducting a study include the planning, design, data collection, analysis, meaningful interpretation and reporting of the research findings. The statistical analysis gives value to the meaningless numbers, breathing life into useless results. The findings and inferences are correct only when use is made of proper statistical tests. This article will attempt to familiarize the reader with the basic methods of science adopted while performing this science.

\section{Instruments Deployed for the Experiments}

The following instrument was deployed for carrying out experiments of mechanical properties on the welded and unwelded mild steel plates of different thickness as shown in Figure 1 [20].

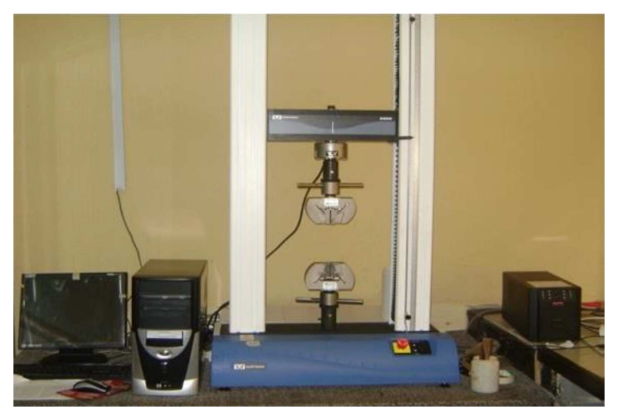

Figure 1. Universal Instron Machine, Model 3369, Maker (Instron).

\section{Tensile Test on Different Thicknesses of Mild Steel Plate Specimens with Manual, Developed Robot Welding and Control Operations}

The results and analyses of the tensile strength test of unwelded mild steel plates for different thicknesses without welding operation, which serves as control specimens are shown in Table 1. The aim of the test was to determine the tensile stress and tensile strain of the welded and un-welded mild steel samples.

Table 1. Tensile test on different thicknesses of mild steel plate specimens with manual, developed robot welding operations and without welding operation (control).

\begin{tabular}{llllll}
\hline $\begin{array}{l}\text { Specimen/Gauge } \\
(\mathbf{m m})\end{array}$ & $\begin{array}{l}\text { Tensile Stress } \\
(\mathbf{M P a})\end{array}$ & $\begin{array}{l}\text { Tensile Strain } \\
(\mathbf{m m} / \mathbf{m m})\end{array}$ & $\begin{array}{l}\text { Tensile Stress } \\
(\mathbf{M P a})\end{array}$ & $\begin{array}{l}\text { Tensile Strain } \\
(\mathbf{m m} / \mathbf{m m})\end{array}$ & $\begin{array}{l}\text { Tensile Stress } \\
(\mathbf{M P a})\end{array}$ \\
\cline { 2 - 6 } & Control & & Robot welded & & $\begin{array}{l}\text { Tensile Strain } \\
(\mathbf{m m} / \mathbf{m m})\end{array}$ \\
\hline 0.5 & 99.70493 & 0.05733 & 87.54535 & 0.021948 & Manually welded \\
0.6 & 146.54387 & 0.10733 & 58.59743 & 0.019532 & 90.7051 \\
\hline
\end{tabular}




\begin{tabular}{lllllll}
\hline $\begin{array}{l}\text { Specimen/Gauge } \\
(\mathbf{m m})\end{array}$ & $\begin{array}{l}\text { Tensile Stress } \\
(\mathbf{M P a})\end{array}$ & $\begin{array}{l}\text { Tensile Strain } \\
(\mathbf{m m} / \mathbf{m m})\end{array}$ & $\begin{array}{l}\text { Tensile Stress } \\
(\mathbf{M P a})\end{array}$ & $\begin{array}{l}\text { Tensile Strain } \\
(\mathbf{m m} / \mathbf{m m})\end{array}$ & $\begin{array}{l}\text { Tensile Stress } \\
(\mathbf{M P a})\end{array}$ & $\begin{array}{l}\text { Tensile Strain } \\
(\mathbf{m m} / \mathbf{m m})\end{array}$ \\
\cline { 2 - 7 } & Control & & Robot welded & & Manually welded & \\
\hline 0.7 & 175.13934 & 0.11200 & 109.8256 & 0.016946 & 125.627 & 0.03533 \\
0.8 & 212.69445 & 0.17067 & 136.078 & 0.028058 & 177.957 & 0.085466 \\
0.9 & 269.31944 & 0.14333 & 222.047 & 0.0134 & 234.374 & 0.050264 \\
1.0 & 303.98739 & 0.19733 & 129.6537 & 0.030838 & 279.6685 & 0.045502 \\
\hline
\end{tabular}

Figure 2 shows variation in tensile stress on weld and unwelded mild steel plates (specimens) of different sizes in which the un-welded (CONTROL) samples gave the highest. Developed robot welding sample gave the lowest. This was expected of the developed robot welding samples given their comparatively higher hardness and lower extension values over both the electric arc welding and un-welded (CONTROL) Samples.

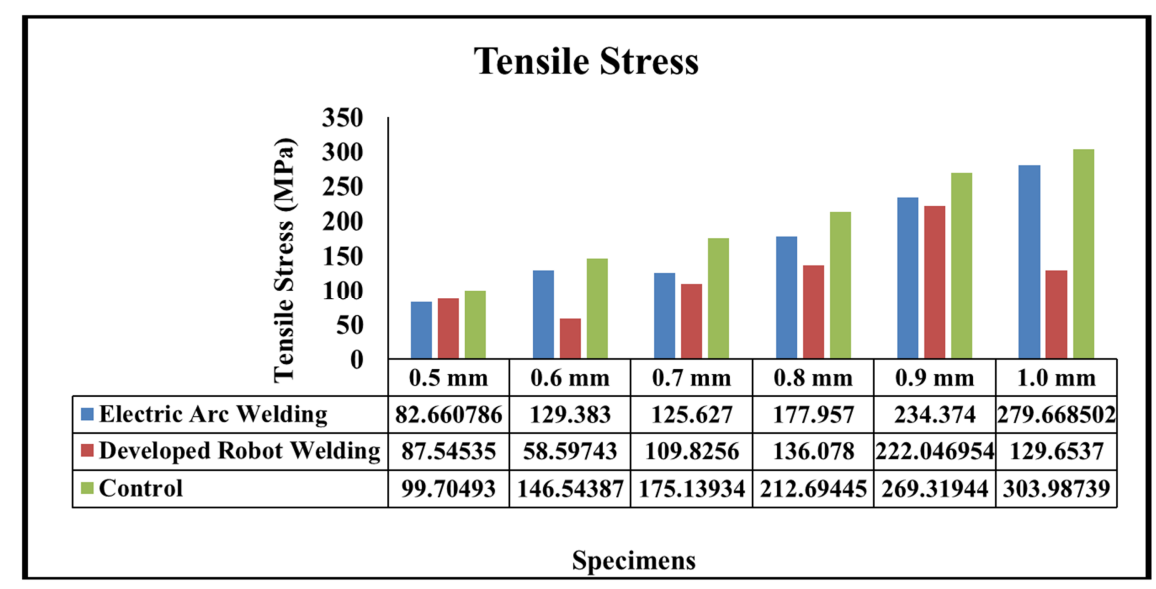

Figure 2. Tensile Stress of Welded and Un-welded Mild Steel Plate Specimen for the Tensile Strength Test.

Figure 3 shows the variation in tensile strain on welded and un-welded mild steel plates (specimens) of different sizes in which the un-welded (CONTROL) samples gave the highest values while developed robot welding samples gave the lowest. This was expected since developed robot welding samples had comparatively higher hardness, lower extension and lower tensile stress values over both the electric arc welding and un-welded (CONTROL) values.

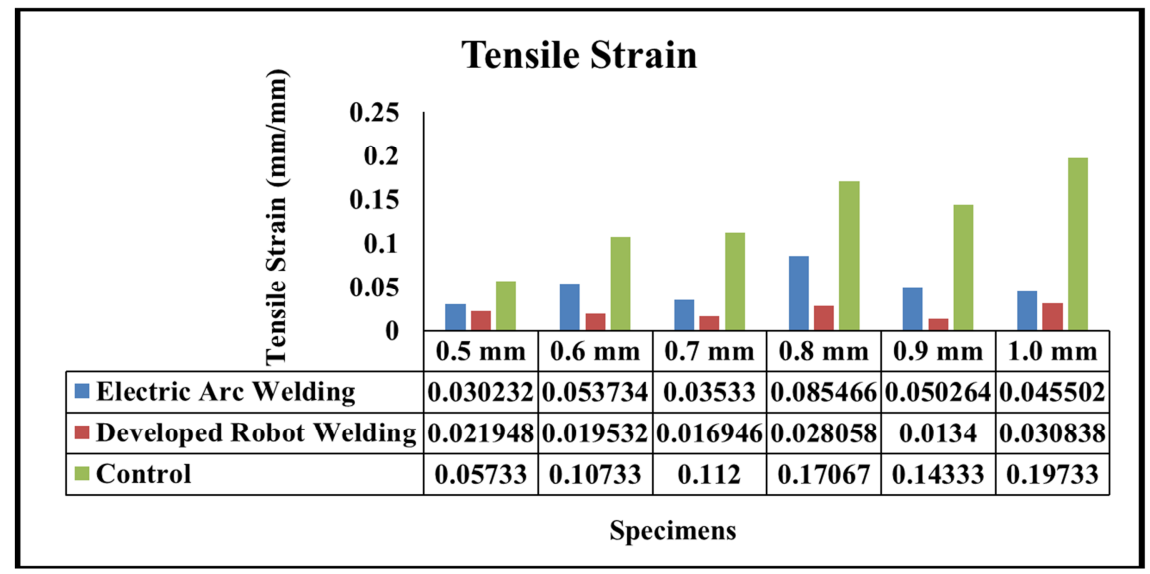

Figure 3. Tensile Strain of Welded and Un-welded Mild Steel Plate Specimen for the Tensile Strength Test.

\section{Statistical Analyses Results and Discussion}

The statistical tools adopted in this research include; descriptive statistics, ANOVA analysis, test of homogeneity of Variances and Post Hoc test (Least Significant Differences) while the software deployed for the analysis is Statistical Package of Social Sciences (SPSS version 2016).

\subsection{Statistical Analysis of the Tensile Stress of Welded and Un-Welded Mild Steel Plate Specimens}

Tables 2, 3 and 4 show the statistical analysis of the tensile stress of welded and un-welded mild steel plate specimens. Table 2 reveals the descriptive statistics of the tensile stress in which the developed robot welding samples collectively have the lowest mean value of 123.96, standard deviation value of 55.85 and variance value of 3119.22 . Table 3 shows homogeneity of variance among tensile stresses of the 
samples in which the result reveals that there is no variation in the tensile stresses among the tests of the samples since pvalue is 0.526 . Table 4 shows in the ANOVA test result that there is no significant difference in the tensile stresses of the samples since $\mathrm{p}$-value is 0.185 .

Table 2. Descriptive Statistics of the Tensile Stress of the Samples.

\begin{tabular}{|c|c|c|c|c|c|c|c|c|c|}
\hline & \multirow{2}{*}{$\mathbf{N}$} & \multirow{2}{*}{ Mean } & \multirow{2}{*}{$\begin{array}{l}\text { Std. } \\
\text { Deviation }\end{array}$} & \multirow{2}{*}{ Variance } & \multirow{2}{*}{$\begin{array}{l}\text { Std. } \\
\text { Error }\end{array}$} & \multicolumn{2}{|c|}{ 95\% Confidence Interval for Mean } & \multirow{2}{*}{ Minimum } & \multirow{2}{*}{ Maximum } \\
\hline & & & & & & Lower Bound & Upper Bound & & \\
\hline Control & 6 & 201.23 & 76.56 & 5861.43 & 31.26 & 120.89 & 281.57 & 99.70 & 303.99 \\
\hline Electric Arc Welding & 6 & 171.61 & 74.12 & 5493.77 & 30.26 & 93.83 & 249.39 & 82.66 & 279.67 \\
\hline Developed Robot Welding & 6 & 123.96 & 55.85 & 3119.22 & 22.80 & 65.35 & 182.57 & 58.60 & 222.05 \\
\hline Total & 18 & 165.60 & 73.01 & 5330.46 & 17.21 & 129.30 & 201.91 & 58.60 & 303.99 \\
\hline
\end{tabular}

Table 3. Test of Homogeneity of Variances among Tensile Stress of the Samples.

\begin{tabular}{llll}
\hline Levene Statistic & df1 & df2 & Sig. (p-value) \\
\hline 0.671 & 2 & 15 & 0.526 \\
\hline
\end{tabular}

Table 4. ANOVA Test of the Tensile Stress of the Samples.

\begin{tabular}{llllll}
\hline & Sum of Squares & Df & Mean Square & F calc. & Sig. (p-value) \\
\hline Between Groups & 18237.16 & 2 & 9118.58 & 1.89 & 0.185 \\
Within Groups & 72371.16 & 15 & 4824.74 & & 3.68 \\
Total & 90608.32 & 17 & & & \\
\hline
\end{tabular}

\subsection{Statistical Analysis of the Tensile Strain of Welded and Un-Welded Mild Steel Plate Specimens}

Tables 5, 6, 7 and 8 show the statistical analysis of the tensile strain of welded and un-welded mild steel plate specimens. Table 5 reveals the descriptive statistics of the tensile strain in which the developed robot welding samples collectively have the lowest mean value of 0.022 , standard deviation value of 0.007 and variance value of 0.001 . Table 6 shows homogeneity of variance among tensile strains of the samples in which the result reveals that there is variation in the tensile strains among the tests of the samples since p-value is 0.008 .

Table 7 shows in the ANOVA test result that there is significant difference in the tensile strains of the samples in which developed robot welding operation gave the lowest tensile strains compared with electric arc welding and unwelded (CONTROL) since $\mathrm{p}$-value is 0.001 . Table 8 shows the mean difference of -0.109 between developed robot welding and un-welded (CONTROL) samples and -0.028 between developed robot welding and electric arc welding samples.

Table 5. Descriptive Statistics of the Tensile Strain of the Samples.

\begin{tabular}{|c|c|c|c|c|c|c|c|c|c|}
\hline & \multirow{2}{*}{$\mathbf{N}$} & \multirow{2}{*}{ Mean } & \multirow{2}{*}{$\begin{array}{l}\text { Std. } \\
\text { Deviation }\end{array}$} & \multirow{2}{*}{ Variance } & \multirow{2}{*}{$\begin{array}{l}\text { Std. } \\
\text { Error }\end{array}$} & \multicolumn{2}{|c|}{ 95\% Confidence Interval for Mean } & \multirow{2}{*}{ Minimum } & \multirow{2}{*}{ Maximum } \\
\hline & & & & & & Lower Bound & Upper Bound & & \\
\hline Control & 6 & 0.131 & 0.050 & 0.0025 & 0.020 & 0.079 & 0.184 & 0.057 & 0.197 \\
\hline Electric Arc Welding & 6 & 0.050 & 0.019 & 0.0004 & 0.008 & 0.030 & 0.070 & 0.030 & 0.085 \\
\hline Developed Robot Welding & 6 & 0.022 & 0.007 & 0.0001 & 0.003 & 0.015 & 0.029 & 0.013 & 0.031 \\
\hline Total & 18 & 0.068 & 0.056 & 0.0036 & 0.013 & 0.040 & 0.096 & 0.013 & 0.197 \\
\hline
\end{tabular}

Table 6. Test of homogeneity of variances among Tensile Strain of the samples.

\begin{tabular}{llll}
\hline Levene Statistic & df1 & df2 & Sig. (p-value) \\
\hline 6.724 & 2 & 15 & 0.008 \\
\hline
\end{tabular}

Table 7. ANOVA Test of the Tensile Strain of the Samples.

\begin{tabular}{|c|c|c|c|c|c|c|}
\hline & Sum of Squares & Df & Mean Square & F calc. & Sig. (p-value) & F critical \\
\hline Between Groups & 0.039 & 2 & 0.019 & 19.84 & 0.001 & 3.68 \\
\hline Within Groups & 0.015 & 15 & 0.001 & & & \\
\hline Total & 0.053 & 17 & & & & \\
\hline
\end{tabular}

Table 8. Post Hoc test: Least Significant Differences (LSD) for Tensile Strain multiple Comparisons between the Samples.

\begin{tabular}{|c|c|c|c|c|c|c|}
\hline \multirow{2}{*}{ (I) Samples } & \multirow{2}{*}{ (J) Samples } & \multirow{2}{*}{$\begin{array}{l}\text { Mean Difference } \\
\text { (I-J) }\end{array}$} & \multirow{2}{*}{ Std. Error } & \multirow{2}{*}{$\begin{array}{l}\text { Sig. (p- } \\
\text { value) }\end{array}$} & \multicolumn{2}{|c|}{ 95\% Confidence Interval for Mean } \\
\hline & & & & & Lower Bound & Upper Bound \\
\hline \multirow[t]{2}{*}{ Control } & Electric Arc Welding & $0.081^{*}$ & 0.018 & 0.001 & 0.043 & 0.120 \\
\hline & Developed Robot Welding & $0.109^{*}$ & 0.018 & 0.001 & 0.071 & 0.148 \\
\hline \multirow[t]{2}{*}{ Electric Arc Welding } & Control & $-0.081^{*}$ & 0.018 & 0.001 & -0.120 & -0.043 \\
\hline & Developed Robot Welding & 0.028 & 0.018 & 0.139 & -0.010 & 0.067 \\
\hline \multirow[t]{2}{*}{ Developed Robot Welding } & Control & $-0.109^{*}$ & 0.018 & 0.001 & -0.148 & -0.071 \\
\hline & Electric Arc Welding & -0.028 & 0.018 & 0.139 & -0.067 & 0.010 \\
\hline
\end{tabular}




\section{Conclusion}

The robot welding sample produced gave the lowest tensile stress while the un-welded samples (CONTROL) gave the highest. The un-welded (CONTROL) samples gave the highest tensile strain values while the lowest was given by the developed robot welding samples. This implies that the ratio of the deformation to the initial dimension of the material is lesser with the developed robot welding samples when compared with the manual arc welding samples and the un-welded samples. While the un-welded samples exhibited the highest amount of deformation under stress. Therefore, it is evident that the welding processes have significant impact on the tensile stress and strain properties of the welded mild steel plates and that good welding quality can be achieved more with the developed welding robot.

\section{Recommendation}

For a minimum deformation and a good arc welding quality, the developed welding robot with its comparative advantages is therefore recommended for automation of welding processes.

\section{References}

[1] Radaj, D. and Sonsino, C. M. (1998). Fatigue assessment of welded joints by local approaches. Cambridge: Abington Publication.

[2] Haibach, E. (1968). Fatigue Strength of Welded Joints from Viewpoint of Local Strain Measurement (in German). Report FB77, Fraunhofer- Institut für Betriebsfestigkeit (LBF), Darmstadt.

[3] Atztori, G. and Meneghetti, G. (2001). Fatigue strength of filled welded structural steels: finite elements, strain gauges and reality. International Journal of Fatigue, 23: 713-21.

[4] van Wingerde, A. M., Packer, J. A. and Wardenier, J. (1995). Criteria for the fatigue assessment of hollow structural section connections. J Construct Steel Res; 35: 71-115.

[5] Matoba, M., Kawasaki, T., Fujii, T. and Yamauchi, T. (1983). Evaluation of fatigue strength of welded structures-hull's members, hollow section joints, piping and vessel joints. IIWDoc. XIII-1082-83, International Institute of Welding.

[6] Radaj, D. (1990). Design and analysis of fatigue-resistant welded structures. German Edition: DVS-Verlag, Du"sseldorf 1985; English Edition: Abington Publ., Cambridge.

[7] Petershagen, H., Fricke, W. and Massel, T. (1991). Application of the local approach to the fatigue strength assessment of welded structures in ships. IIW Doc. XIII-1409-91, International Institute of Welding.

[8] Fricke, W. and Petershagen, H. (1992). Detail design of welded ship structures based on hot spot stresses. In: Caldwell JB, Ward G, editors. Practical design of ships and mobile units. Elsevier Science.

[9] Niemi, E. (1995). Recommendations concerning stress determination for fatigue analysis of welded components. Cambridge: Abington Publication.

[10] Huther, I., Gorski, S., Lieurade, H. P., Laborde, S. and Recho, N. (1999). Longitudinal non loaded welded joints geometrical stress approach. Welding in the World, 43 (3): 20-6.

[11] Fricke, W. (2002). Recommended hot spot analysis procedure for structural details of ships and FPSOs based on round-robin FE analyses. International Journal of Offshore and Polar Engng, 12 (1): 40-7.

[12] Niemi, E. and Tanskanen, P. (2000). Hot spot stress determination for welded edge gussets. Welding in the World; 44 (5): 31-7.

[13] Fricke, W. and Bogdan, R. (2001). Determination of hot spot stress in structural members with in-plane notches using a coarse element mesh. IIW-Doc. XIII-1870-01, International Institute of Welding.

[14] Niemi, E. (2001). Structural Stress Approach to Fatigue Analysis of Welded Components-Designer's Guide. IIWDoc. XIII-1819-00/XV-1090-01 (Final Draft), International Institute of Welding.

[15] Dong, P. (2001). A structural stress definition and numerical implementation for fatigue analyses, International Journal of Fatigue, 23 (10): 865-76.

[16] Dong, P., Hong, J. K. and Cao, Z. (2001). A mesh- insensitive structural stress procedure for fatigue evaluation of welded structures. IIW- Doc. XIII-1902-01/XV-1089- 01, International Institute of Welding.

[17] Doerk, O. Fricke, W. and Weissenborn, C. (2003). Comparison of different calculation methods for structural stresses at welded joints, International Journal of Fatigue, 25: 359-369.

[18] Kim, W. S., Kim, D. H, Lee, S. G. and Lee, Y. K. (2001). Fatigue strength of load carrying box fillet weldment in ship structure. In: Wu Y-S, Cui W-C, Zhou G-J, editors. Practical design of ships and other floating structures. Elsevier Science.

[19] Paetzold, H. and Doerk, O. and Kierkegaard, H. (2001). Fatigue behaviour of different bracket connectons. In: Wu Y-S, Cui W-C, Zhou G-J, editors. Practical design of ships and other floating structures (Ed. Elsevier).

[20] Oladebeye, D. H., Adejuyigbe, S. B. and Kareem, B. (2020). Metallurgical Analyses of Welding Using a Developed MiniRobot. American Journal of Mechanical and Materials Engineering, 4 (2): 26-36. 